\title{
THE THAMIN OR ELD'S DEER, IN BURMA
}

The following information has been received from $U$ Tun Yin, Burma Civil Service (retired), and Maung Gale, Divisional Forest Officer, Shwebo.

For a map of Burma, see " Wild Life Preservation in Burma", Oryx, Volume III, No. 2.

In 1954 and 1955 the Forest Department conducted a survey to discover the number of thamin in Burma, and it is now estimated that there are between 3,000 and 3,500.

Thamin are plentiful in Shwebo, East Katha, Lower Chindwin, Minbu, Meiktila, Thayetmyo and Allanymo divisions ; few in West Katha, Yaw, Zigon and Prome divisions; rare in Yamethin division.

Shwebo contains the largest number with over a thousand animals. Information is lacking from Bassein-Henzada Division. Thamin were found in the Shwethamin Reserve of this division in 1940. Recent information is also lacking from the Arakan division, though Lieut.-General A. F. Phillip Christisen saw thamin on two or three occasions during the Arakan campaign of Autumn, 1943, to May, 1945. (J.B.N.H.S., vol. 45 (4), Dec., 1945.) It is possible that the thamin seen by General Christisen may have been the Manipur subspecies which have wandered into Arakan from East Pakistan.

In the heart of the thamin country is Kyatthin Sanctuary, 104 square miles. Here a gamekeeper is appointed, as funds permit, to look after the reserve and report the wild life situation. His reports and those from villagers show that the thamin have not only survived but have increased. The latest estimate is about 500 animals, which is not considered too large for this sanctuary, though some of them may only have come in temporarily from the surrounding forest reserves.

Other animals occasionally seen in the reserve include saing (banteng) and gyi (muntjac). White-winged wood duck have been reported as frequenting the small lakes and pools from November to February, but they do not breed there.

Unfortunately, duc to generally unsettled conditions throughout the Shwebo Forest Division, thamin can not yet be protected from the poacher's gun. Nevertheless, it is heartening to know that they are not dying out but even, in certain areas, increasing.

Thamin are completely protected under the Burma Wild Life Protection Act, 1936. 